\title{
Ron K. Pickerill and the genesis of ichnology in the Antilles (Jamaica and Carriacou)
}

\author{
STEPHEN K. Donovan
}

Department of Geology, Naturalis Biodiversity Center, Darwinweg 2, 2333 CR Leiden, The Netherlands

<steve.donovan@naturalis.nl>

Date received: 03 February 2015 g Date accepted: 06 June 2015

\begin{abstract}
Antillean ichnology was essentially a blank book when Ron Pickerill of the University of New Brunswick, Fredericton, made his first research visit to Jamaica in February 1990. Ron's first Jamaican trace-fossil research team worked initially on the Paleogene Richmond Formation, a flysch succession. Subsequent fieldwork examined the diverse sedimentary formations of the Neogene Coastal Group. Ron's encyclopaedic knowledge of ichnotaxonomy and his enthusiasm for fieldwork led the team in many directions. Investigations were integrated with new studies of the island's sedimentology and paleontology. For example, the description of the ichnology and sedimentology of the Upper Pliocene Bowden Formation, including the internationally famous Bowden shell bed, was part of a much wider study. The case-hardened rocks of the White Limestone Group discouraged detailed study until Donovan Blissett attacked the diverse ichnobiota of these user-unfriendly rocks for his doctorate under Ron's supervision at the University of New Brunswick. Carriacou in the Grenadines was the other island to receive detailed examination in terms of its ichnofauna by Ron and his co-workers. The east coast of this small island provides a near-continuous exposure of the deep water succession of the Grand Bay Formation. Deeper-water burrows and borings in allochthonous bioclasts derived from the shallow shelf provide ichnological contrast in this formation.
\end{abstract}

\section{RÉSUMÉ}

On ne connaissait essentiellement rien de l'ichnologie antillaise lorsque Ron Pickerill, de l'Université du Nouveau-Brunswick à Fredericton, a effectué sa première visite de recherche en Jamaïque en février 1990. La première équipe de recherche sur les ichnofossiles jamaïcains de Ron a initialement travaillé sur la formation du Paléogène de Richmond, une séquence de flysch. Au cours de travaux subséquents sur le terrain, léquipe a examiné les diverses formations sédimentaires du groupe Coastal du Néogène. Les connaissances encyclopédiques de l'ichnotaxonomie de Ron et son enthousiasme pour le travail sur le terrain ont mené l'équipe dans maintes directions. Des investigations ont été intégrées aux nouvelles études de la sédimentologie et de la paléontologie de l'île. La description de l'ichnologie et de la sédimentologie de la formation de Bowden du Pliocène supérieur, notamment le lit coquillier de renommée internationale de Bowden, s'est par exemple inscrite dans une étude beaucoup plus large. Les roches cémentées du groupe de White Limestone ont découragé une étude détaillée jusquà ce que Donovan Blissett s'attaque à l’ichnobiote de ces roches inconviviales pour son doctorat sous la surveillance de Ron à l'Université du Nouveau-Brunswick. Carriacou dans les Grenadines a été l'autre île à faire l'objet d'un examen détaillé de son ichnofaune par Ron et ses collègues. La côte est de cette petite île présente un affleurement quasi continu de la succession en eau profonde de la formation de Grand Bay. Les tubes en eau plus profonde et les perforations dans les roches bioclastiques allochtones provenant de la plate-forme interne offrent un contraste ichnologique à l'intérieur de cette formation.

[Traduit par la redaction] 


\section{INTRODUCTION}

I was appointed as a lecturer in the Department of Geology at the University of the West Indies, Mona (UWI), in mid-December 1985, following an informal telephone interview with T.A. Jackson, the head of department at that time. In the five or so weeks before I flew to Kingston, I gained impressions about Jamaica, its geology and fossil record from informed discussions with knowledgeable colleagues. One prevalent opinion was that many aspects of the island's fossil record were already adequately documented. For example, the fossil echinoids were considered to be well known from, principally, the publications of Hawkins (1923, 1924, 1927), Hawkins in Trechmann (1930) and Arnold and Clark (1927, 1934).

As an echinoderm specialist, this was of particular interest to me. I lost no time in investigating the veracity of this assertion. To cut a long story short, the echinoids had been studied in detail from the Upper Cretaceous (mainly specimens collected by C.T. Trechmann while collecting coeval mollusks and sent to H.L. Hawkins) and the Eocene Yellow Limestone Group. Some Eocene specimens were collected by Trechmann and C.A. Matley, but many more bought from road menders by B.W. Arnold (Arnold and Clark 1927, p. 5-6); the rest of the stratigraphic record had been largely ignored (Donovan 1988). Similar remarks could be made about many aspects of the Jamaican fossil biota. Even today, there are many fossil groups from the island that remain poorly studied by paleontologists, largely because Jamaica has a bountiful fossil record and a dearth of devoted specialists. In the late 1980s, these poorly known groups included the trace fossils.

A review of the results of the past 25 years of ichnological research in Jamaica is presented elsewhere (Donovan et al. 2015). Herein, I aim to record some of the other aspects of this work.

\section{PALAEONTOLOGICAL ASSOCIATION ANNUAL MEETING 1989}

The Annual Meeting of the Palaeontological Association (PalAss) always occurs in December and commonly in the UK, and while at UWI I tried to attend most years, at the same time visiting family and undertaking fieldwork in the Paleozoic of the British Isles. In 1989 the meeting was particularly attractive personally as it was being held at the University of Liverpool, where I had studied for my Ph.D. It was good to visit my old university, and at the same to present new data from the Jamaican fossil record (Donovan et al. 1989) and lead a field trip.

Another Liverpool alumnus from distant shores who attended the meeting was R.K. (Ron) Pickerill of the University of New Brunswick (UNB), Fredericton,
Canada (Fig. 1). Ron was, and is, an internationally acclaimed expert on trace fossils. It was over a beer in the conference bar one evening that I lamented to Ron that, if he could get to Jamaica, there was a wellexposed, Paleogene flysch succession (constituting the Richmond Formation) that was just waiting to have its many and varied trace fossils identified and documented. Ron seemed more than a little intrigued by this idea.

Ron was an undergraduate and postgraduate student at the University of Liverpool in the late 1960s and early 1970s. His Ph.D. (Pickerill 1974) was supervised by the late P.J. Brenchley (Donovan et al. 2011). Ron was appointed to a temporary post at UNB in 1974, but made such a positive impression that he is still there as a full professor over 40 years later. His research interests include ichnology and geology of the lower Paleozoic of north Wales, the Paleozoic of eastern Canada and Maine, and the Cenozoic of the Antilles.

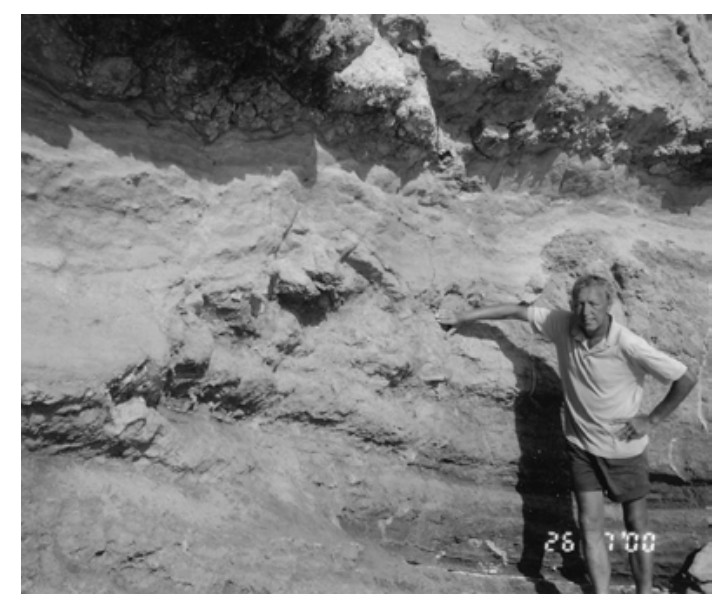

Figure 1. Professor R.K. (Ron) Pickerill in the field in southeastern Carriacou, the Grenadines, in July 2000. His hand is resting on an angular unconformity in a Miocene sedimentary sequence. The underlying Belmont Formation had been burrowed before the deposition of the overlying Kendeace Formation (compare with Donovan et al. 2002, fig. 3).

\section{RICHMOND FORMATION}

My "sales pitch" for the potential of Jamaican ichnology worked far better than I could have hoped. Ron made his first research visit to UWI in Jamaica in February 1990, just two months after the PalAss meeting, and he came again in May of that year. One or two visits per year continued until I left Jamaica in 1998. As explained above, the lack of previous studies on the trace fossils of the island was not due to any lack of material, but to a lack of interest. The first Jamaican trace-fossils research team, led by Ron, 
included myself and the late Hal Dixon (Donovan 2007; Fig. 2A herein). Starting with the Paleogene flysch succession (the Richmond Formation) in the east of the island, subsequent fieldwork moved on to examine the diverse sedimentary formations of the Neogene Coastal Group.

The Richmond Formation (Lower Paleocene to Lower Eocene) of the Wagwater Group is exposed over a considerable area of eastern Jamaica, particularly in the Wagwater Belt and in other areas flanking the Blue Mountain inlier (Robinson 1994; Fig. 3). It consists of about $1200 \mathrm{~m}$ of varied lithofacies, deposited in both shallow- and deep-water marine paleoenvironments, and is essentially part of a large fan-delta submarinefan system (Westcott and Etheridge 1983; Etheridge and Westcott 1984). These rocks have been intensely faulted and folded, have patchy exposure, and may be highly weathered except where exposed by frequent landslides.

The first field season on the Richmond Formation was brief, just five days in February, and involved visits to sites known to Hal Dixon and me. It included a lot of driving to reach productive exposures in eastern Jamaica. Within a month Ron had written a draft of the first research paper on Jamaican trace fossils (Pickerill and Donovan 1991), although Ron's first publication on the island's geology followed a Geological Society of Jamaica field excursion in May 1990 (Donovan et al. 1990). Research on the Richmond Formation mainly occurred in the early 1990s (Fig. 2D), and over the past 25 years has yielded 22 ichnotaxa (Donovan et al. 2015, table 1) occurring in two water-depth-related associations (Donovan et al. 1990, 2005; Pickerill and Donovan 1991; Pickerill et al. 1992, 1993c; Pickerill and Mitchell 1999; Fig. 4 herein). Ichnotaxa are more diverse in the deeper-water deposits of the Formation, but this may be because such deposits are more commonly exposed.

Of the two associations, the Thalassinoides ichnocoenosis reflects shallower-water, representing marginal-marine to shallow-water paleoenvironments. Marginal-marine deposits are thick- to thin-bedded sandstones and mudrocks with pebbly sandstones, conglomerates and rare in-situ coals (Pickerill et al. 1992, fig. 4). In slightly
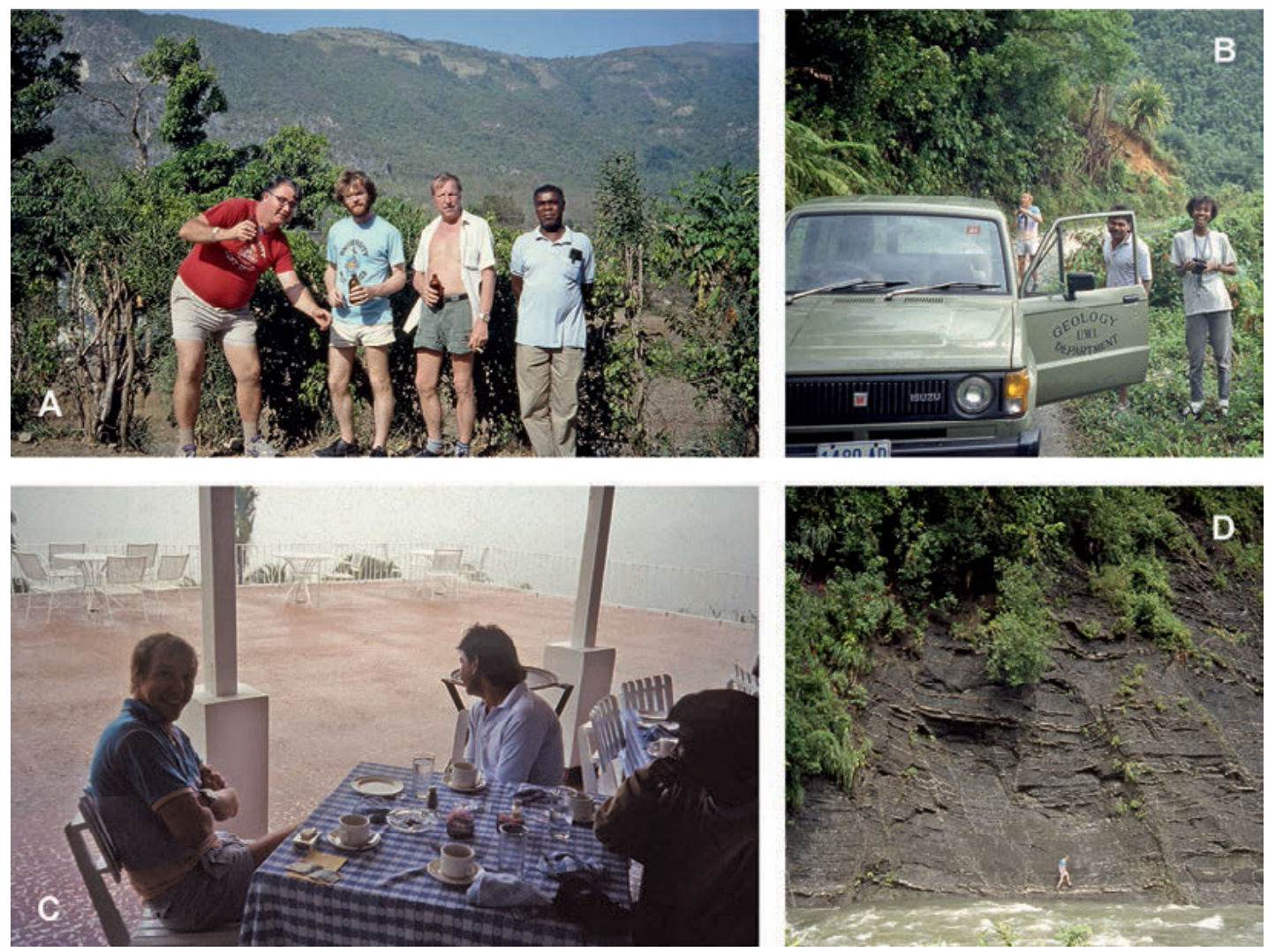

Figure 2. Trace fossil researchers in the field in Jamaica, early 1990s. (A) Left to right, the author, Eamon Doyle, Ron and the late Hal Dixon. Judgement Cliff, near Yallahs, in the background. (B) Russell Maharaj and Carla Gordon, with Ron in the background. (C) Breakfast in Port Antonio. Ron, Russell and a well wrapped up Carla wait for the unseasonable February 1990 rain to stop. (D) Ron in the Rio Grande valley (Pickerill and Donovan 1991, locality 6) in February 1990. Note the white water; the river was in flood and the only way for Ron to cross was by swimming. Hal Dixon and I watched, and stayed dry. 


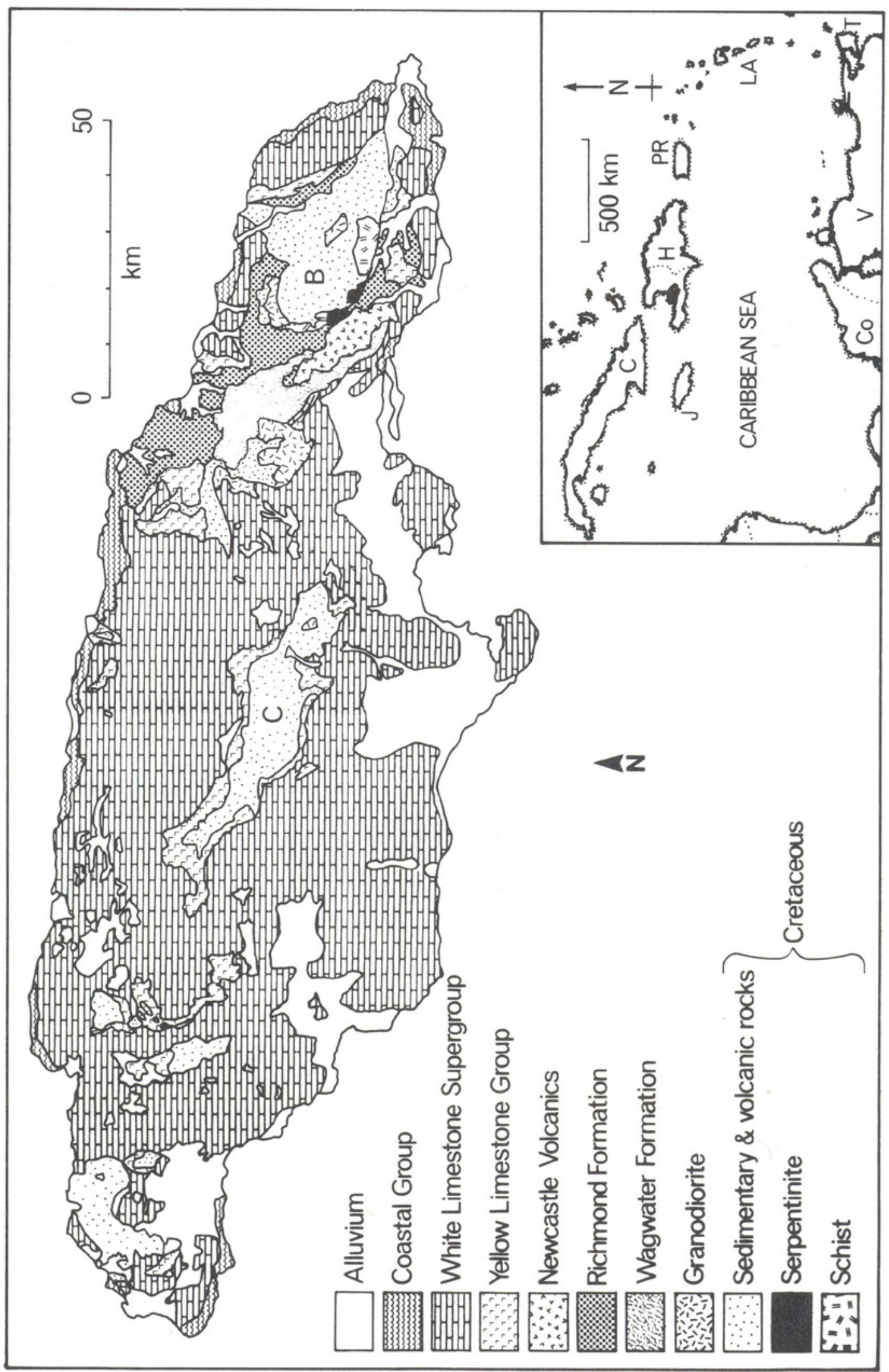


Figure 3. (previous page) Simplified geological map of Jamaica, showing the principal stratigraphical units (after Donovan 1993, fig. 1; Donovan et al. 1995, fig. 1; based on Geological Survey Department 1959; see also McFarlane 1977). Key: B = Blue Mountain inlier; $\mathrm{C}=$ Central inlier. Ages of principal Cenozoic units: granodiorite $=$ Late Cretaceous to Paleocene; Wagwater Formation, Newcastle Volcanics = Paleocene; Richmond Formation = Paleocene to Early Eocene; Yellow Limestone Group = Early to Middle Eocene; White Limestone Supergroup = Middle Eocene to Late Miocene; Coastal Group $=$ Late Miocene to Quaternary; alluvium $=$ Quaternary. The inset map shows the position of Jamaica in the Caribbean. Key (clockwise from Jamaica): J = Jamaica; $\mathrm{C}=\mathrm{Cuba} ; \mathrm{H}=$ Hispaniola (Haiti and Dominican Republic); PR = Puerto Rico; LA $=$ Lesser Antilles; $\mathrm{T}=$ Trinidad $\mathrm{V}=$ Venezuela; $\mathrm{Co}=$ Colombia .
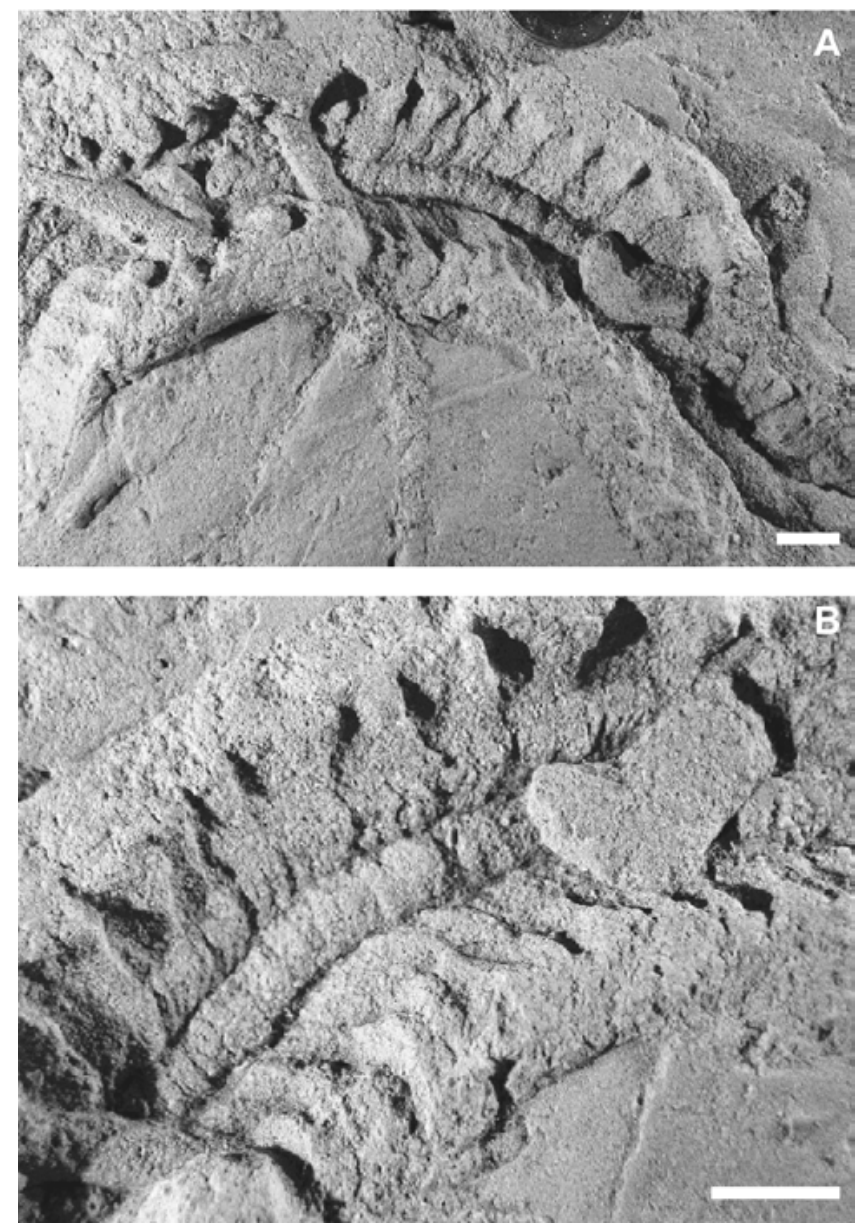

Figure 4. Scolicia prisca, Naturalis Biodiversity Center, Leiden [RGM] 188 697, Paleogene Richmond Formation, Scolicia ichnocoenosis, Jamaica (after Donovan et al. 2005, fig. 1). (A) General view of more sinuous, better preserved part of specimen (from lower right to upper centre to middle left); note cross cutting Planolites isp. cf. P. beverleyensis in the left side of this view. (B) Reoriented enlargement of right side of (A). The $\mathrm{V}$-shaped burrow (upper right) may be either two separate specimens that cross-cut both each other or, more probably, a single, strongly curved example of Planolites isp. cf. P. beverleyensis. Scale bars represent $10 \mathrm{~mm}$. deeper, but still shallow-water deposits, thick- to thinbedded sandstones and mudrocks occur with thin nodularlimestone layers, and with lenses with scleractinian corals and oysters (Pickerill et al. 1992, table 1). The Thalassinoides ichnocoenosis of Pickerill and Donovan (1991; see also Pickerill et al. 1992) is named after its most characteristic and numerically abundant ichnotaxon, Thalassinoides suevicus (Pickerill and Donovan 1991, fig. 6D), probably the spoor of mud shrimps. This ichnocoenosis is interpreted as being inhabited by detritus-feeding crustaceans (Thalassinoides), anemones (Conichnus) and suspensionfeeding or predatory annelids (Arenicolites, Palaeophycus, Planolites and Skolithos), and also includes rare bivalve borings (Teredolites) in wood that was presumably floating.

The other association, the Scolicia ichnocoenosis, has a greater diversity of ichnotaxa -18 , including the three facies-crossing ichnospecies (Donovan et al. 2015, table 1). But about half of these are rare: for example, Paleodictyon? isp. in the Richmond Formation is based on only a small, very incomplete fragment of a network (Pickerill et al. 1993c, p. 64, fig. 2c). The trace fossils in the Scolicia ichnocoenosis are found in thin- to thick-bedded, channelized or, more commonly, non-channelized, turbiditic sandstones and mudstones, uncommonly conglomeratic (Pickerill et al. 1995). This ichnocoenosis is restricted to turbidite sequences formed in deep-water environments. It is named after Scolicia isp. cf. S. plana, which is characteristic of this facies (Pickerill and Donovan 1991, p. 32, figs 4, 5), although not necessarily abundant. The common ichnospecies are simple burrow systems. Graphoglyptids such as Paleodictyon are particularly characteristic of turbiditic flysch successions, but are rare in the Richmond Formation (see Pickerill et al. 1992, pp. 65-66, for discussion). The Scolicia burrows are interpreted as being inhabited by spatangoid echinoids (Scolicia; Fig. 4), and a variety of deposit- and suspensionfeeding or predaceous crustaceans and vermiform organisms, predominantly annelids (Pickerill and Donovan 1991, p. 32).

The earlyfield effort was supportedby others, such as UWI masters students Russell Maharaj and Carla Gordon (Fig. 2B, C). They provided keen eyes, and Russell drove the fieldwork vehicle when Hal Dixon was not available (Fig. 2B). Eamon Doyle was sedimentologist at UWI for four years in the early 1990s (Fig. 2A), and contributed to studies of the Richmond Formation and Coastal Group (e.g., Pickerill et al. 1993a, b). 


\section{COASTAL GROUP}

Pickerill and co-workers did not progress immediately upwards through the Jamaican stratigraphic succession, but rather leapfrogged over the middle Cenozoic limestones to arrive at the Coastal Group. The reason for this is that the Coastal Group has the advantages of excellent coastal exposures and diverse ichnofossils without the disadvantages, particularly in the White Limestone Group, of karstification and case hardening.

Before revision by James-Williamson and Mitchell (2012), the present Coastal Group was separated into the Lower Coastal Group (essentially Mio-Pliocene) and the Upper Coastal Group (Pleistocene). I have retained the older terminology here as it was used in the original papers; thus, the Bowden Formation of the Lower Coastal Group is not reduced here member status.

The Lower Coastal Group sensu Robinson (1968) is composed of the deeper-water Buff Bay and Bowden formations, and the shallower-water August Town Formation. To these should be added the Hopegate Formation, a raised reef coeval with the Bowden Formation, but previously thought to be Pleistocene. Trace fossils have been described from both the Bowden and August Town formations. Sporadic studies of the trace fossils of the August Town Formation have concentrated on the particularly well-exposed coastal succession of the Round Hill beds, south-central Jamaica (Donovan and Miller 1999; Donovan et al. 2015, table 4). Pickerill et al. (1993a) provided the only detailed description of a trace fossil from these beds, namely the rosette-shaped burrow Dactyloidites ottoi.

The Upper Pliocene Bowden Formation of south-east Jamaica has provided a focus for more intense investigations (Pickerill et al. 1996, 1998b; Mitchell et al. 1998; Pickerill and Donovan 1998, 1999; Donovan et al. 2014a, b) and has produced two disparate assemblages (Donovan et al. 2015, table 4). This unit was researched by Ron and co-workers in the mid-1990s, aided by David Keighley, then a graduate student supervised by Ron and now a professor at UNB, who was in Jamaica as my sabbatical replacement (1994-1995).

The Bowden Formation was laid down in a deepwater environment below storm wave base; its commonest lithofacies is so-called marlstone; that is, thick-bedded, pale-coloured mudrock (Pickerill et al. 1998b; Donovan and Pickerill 2013). These finer-grained siliciclastic rocks have yielded a suite of burrows; the only borings are dense Teredolites longissimus in a foundered log (Pickerill et al. 1996). In contrast, the coarser-grained mass-flow deposits of the Bowden shell beds of the Bowden Formation (which consists of conglomerates and coarse-grained sandstones; Pickerill et al. 1998b, figs 2, 3) lack burrows, but are rich in allochthonous lithoclasts and shells that were derived from shallower water. These lithoclasts and shells bear a suite of borings that are similar to those of shallow- water deposits of the Upper Coastal Group (Pickerill and Donovan 1999, table 3; Fig. 5 herein). These clasts must have been bored in shallow water and transported downslope.

The diversity of ichnofossils from the five stratigraphic units in the Upper Coastal Group is only slightly more than that in the Lower Coastal Group (Donovan et al. 2015, table 5). Soft-sediment structures are few, and almost half the ichnospecies in the Upper Coastal Group belong to the borings Entobia and Gastrochaenolites. The Upper Pleistocene Port Morant Formation (Mitchell et al. 2000) is a mixed scleractinian-siliciclastic succession, reflected by the ichnospecific diversity of the borings by bivalves assigned to Gastrochaenolites ispp., mainly in large colonial scleractinian corals and strombid gastropods, and by burrows (Ophiomorpha, Palaeophycus and Thalassinoides) in sandstones and so-called marlstones (Pickerill and Donovan 1997; Pickerill et al. 1998a; Donovan 2002a).

The Lower Pleistocene fore-reef limestones of the Manchioneal Formation and sandstones of the Old Pera Formation are approximately coeval (James-Williamson and Mitchell 2012), but very different environmentally and intriguing. Particularly, the Manchioneal Formation awaits detailed ichnological elucidation (Donovan et al. 2001). The most interesting occurrence in either unit is the locally common trace in the Old Pera Formation of anal drains of heart urchins, known as Bichordites monastiriensis (Pickerill et al. 1993b; Donovan et al. 2006, fig. 2).

\section{WHITE LIMESTONE GROUP}

The middle Cenozoic case-hardened rocks of the White Limestone Group discouraged detailed study until Donovan Blissett, a UWI graduate who completed his Ph.D. in Fredericton under Ron's supervision, attacked the diverse ichnobiota of these user-unfriendly rocks. The White Limestone Group can be divided broadly into two major sedimentary units, one of which was shallow water and the other deeper water in origin. Shallow-water units include a lagoonal peneroplid-miliolid-molluscan facies within a restricted tidal-flat platform (Troy and Moneague formations) and an open-water, shelf-edge, coralgal-orbitoid facies (Swanswick, Moneague and Somerset formations). The deeper-water formations, namely the Montpelier Formation (consisting of bedded chert) and the Pelleu Island Formation (which lacks chert), are essentially coccolith planktonicforaminiferalchalkylimestones(Mitchell2004; Blissett2006).

The known trace fossils from this unit include a moderate diversity of poorly to well-preserved soft-sediment ichnotaxa; an uncommon, but relatively diverse group of macroborings; and a common, diverse group of poorly to well-preserved microborings. Eight ichnoassemblages have been identified in the White Limestone Group (Blissett 2006, pp. 305-307; see Donovan et al. 2015 for list of related publications). 


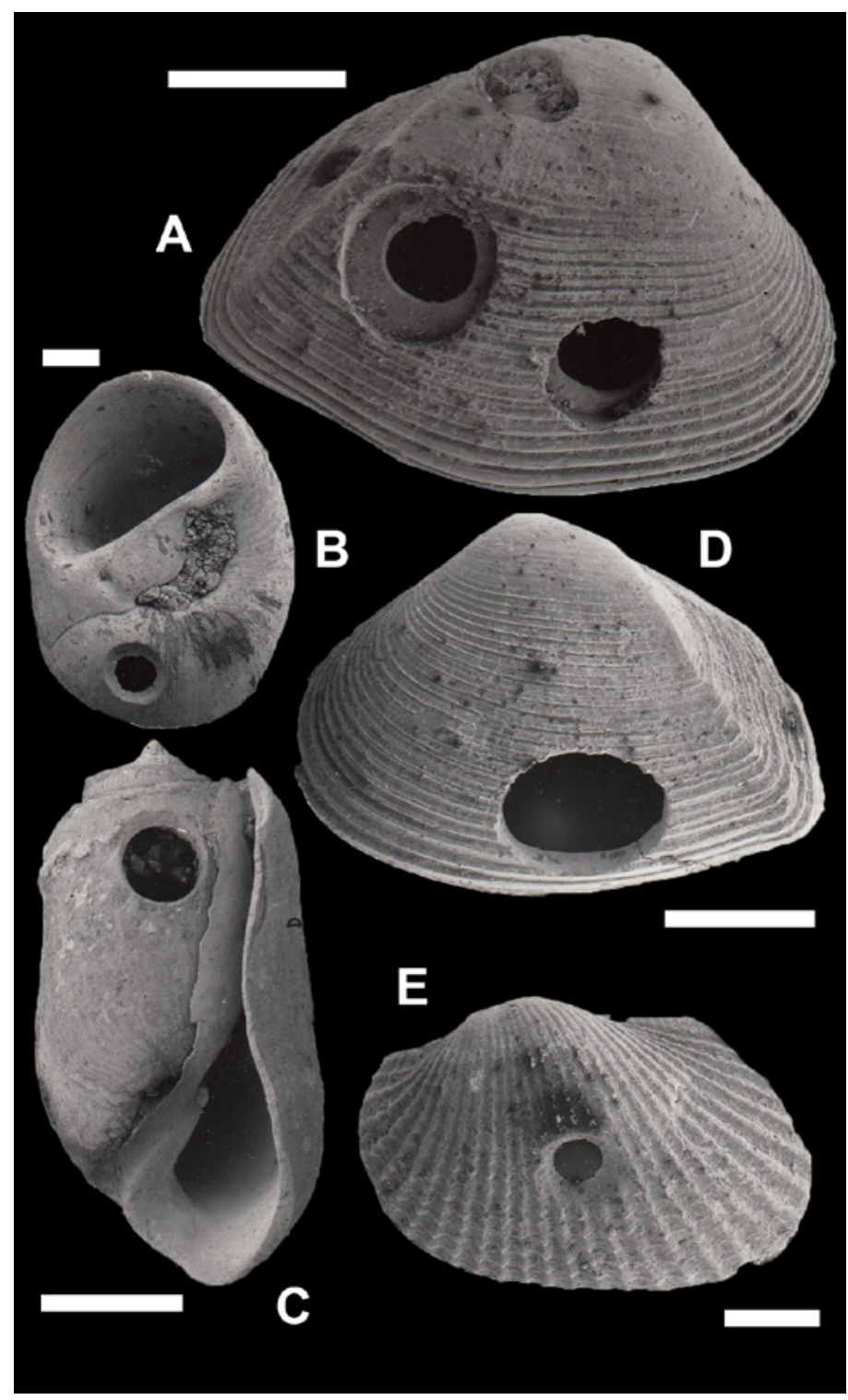

Figure 5. Sedilichnus ispp. from the Upper Pliocene Bowden shell beds, Bowden Formation, southeast Jamaica (after Donovan and Pickerill 1999, fig. 5). (A) Disarticulated right valve of Crassitellites sp. with two successful (= penetrative) and two unsuccessful (near umbo) Sedilichnus simplex. (B) Natica castrenoides penetrated by Sedilichnus paraboloides (possibly evidence of cannibalism). (C) Acetocina lepta penetrated by $S$. paraboloides. (D) Disarticulated left valve of Crassitellites sp. penetrated by large S. simplex. (E) Disarticulated left valve of Barbatia sp. penetrated by $S$. paraboloides. Scale bars represent $10 \mathrm{~mm}$.

\section{CARRIACOU}

Members of the research group led by Ron were keen to extend their investigations elsewhere in the Antilles, but the choice of Carriacou (Fig. 6) in the Grenadines chain, Lesser Antilles, was serendipitous. The author and David Harper (now a professor at Durham University) have collaborated since 1987 on a research program on Antillean brachiopods and crinoids in deep-water sedimentary deposits. Various sources of information suggested that the Miocene of Carriacou might be rich in these fossils. Crinoids and brachiopods are otherwise rare throughout the Cenozoic of the Caribbean region. To cut a long story short, the Middle Miocene Grand Bay Formation of Carriacou is the most productive unit for fossil brachiopods and crinoids in the Antilles.

Relevant to this paper is that the Grand Bay Formation also produced the first deep-water Zoophycos burrow from the region, about $1.3 \mathrm{~m}$ wide, yet incomplete (Donovan and Harper 1999). This discovery precipitated a general study of the Grand Bay Formation, which also drew in Ron, the paleontologist Roger Portell (Florida Museum of Natural History, Gainesville; Fig. 7) and the geochemist Trevor Jackson (then UWI, Mona). This formation is comparable with other deeper-water, turbiditic/mass-flow deposits in the region (Donovan and Harper 1999; Pickerill et al. 2002a, b, 2003; Donovan et al. 2003, 2013) such as the Bowden shell bed of Jamaica (see above). In the Grand Bay Formation there is a suite of autochthonous burrows and trails indicative of the deeper-water depositional environment supplemented by bored clasts derived from shallower water. These occurrences, supplemented by evidence from sedimentology and paleontology (Donovan et al. 2003), were pivotal in confirming the deep-water depositional environment of the Grand Bay Formation (see, for example, Jung 1971), in contrast to its interpretation as a beach deposit (Speed et al. 1993).

\section{DISCUSSION AND CONCLUSION}

Jamaica and the rest of the Antillean region was a poorly known, almost completely ignored backwater for students of ichnology until 1990, when Ron Pickerill first came to Jamaica. Now Jamaica has the best known record of Cenozoic trace fossils in the Greater Antilles, and the Miocene of Carriacou is the most intensely studied succession for trace fossils in the Lesser Antilles. Even in Jamaica, much still remains to be documented and interpreted, such as the Yellow Limestone Group and its diverse sedimentary lithofacies, and the widespread Upper Cretaceous succession. The work is never finished, thank goodness, and it only remains for me to thank Ron for pointing us in the right direction (Fig. 8). 


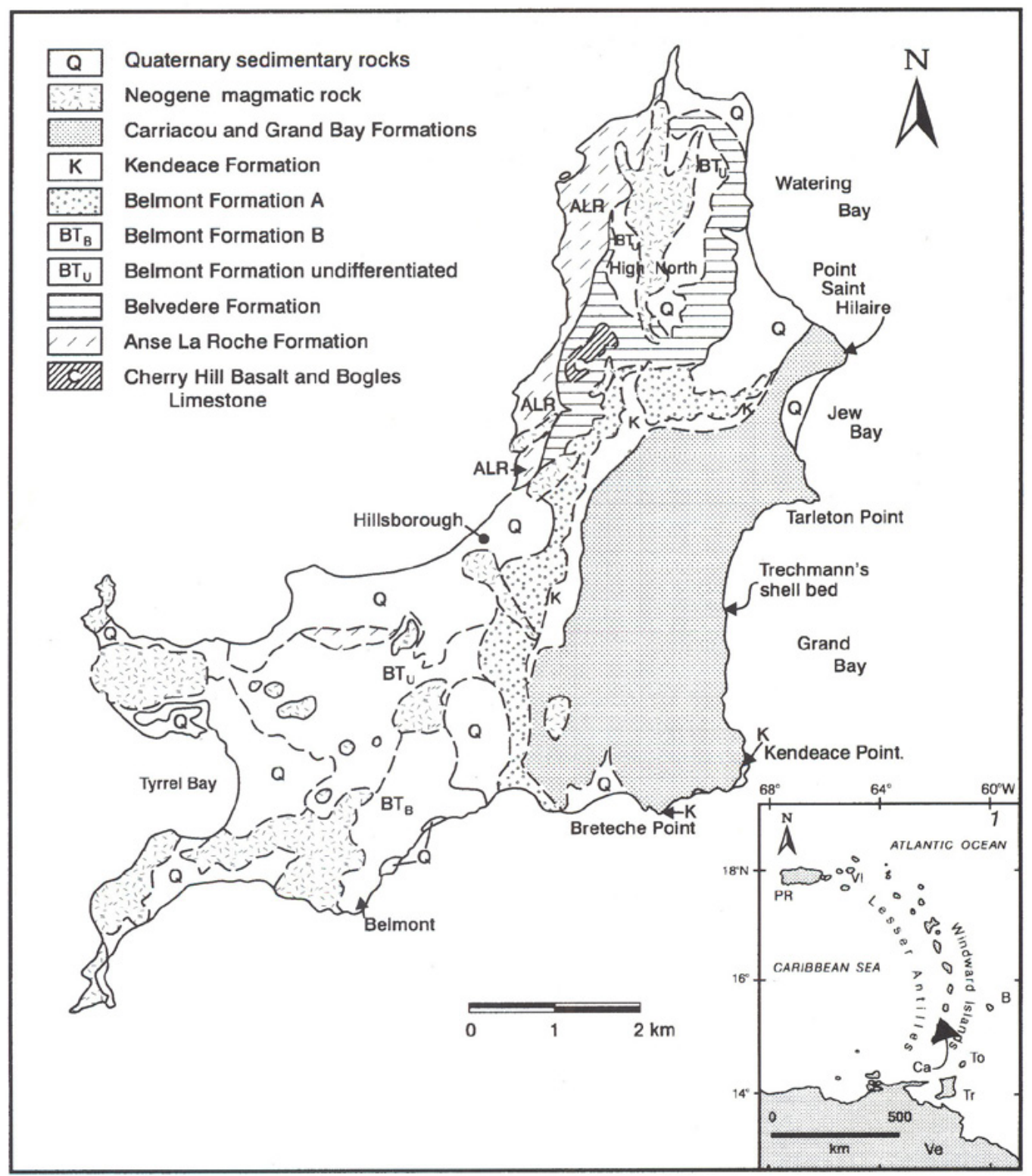

Figure 6. Simplified geological map of Carriacou, modified after Speed et al. (1993) and Jackson (1970), showing principal localities mentioned in text (Donovan et al. 2003, fig. 1). Inset map of Lesser Antillean region shows the position of Carriacou (arrowed). Key: B = Barbados; $\mathrm{Ca}=$ Carriacou; $\mathrm{PR}=$ Puerto Rico; To = Tobago; $\mathrm{Tr}=$ Trinidad; Ve = Venezuela; VI = Virgin Islands.

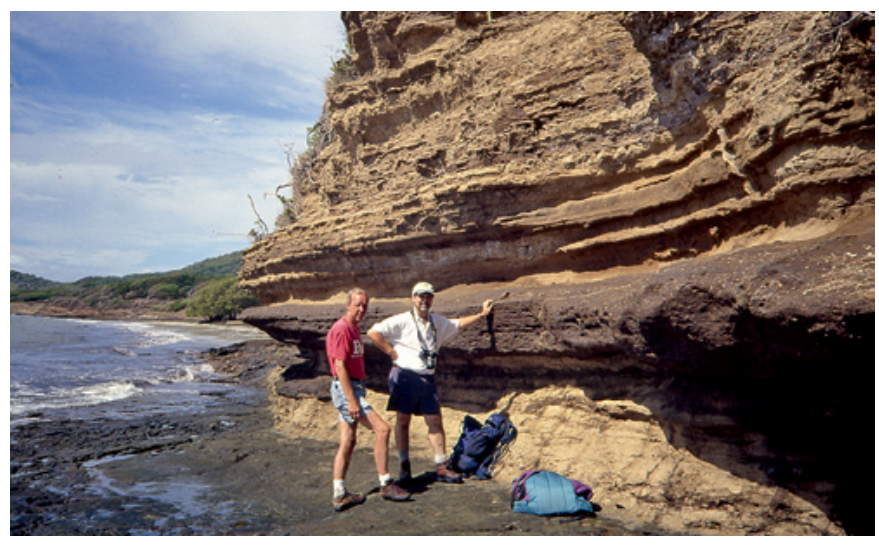

Figure 7. Ron (left) and Roger Portell at Trechmann's shell bed, Grand Bay Formation, east coast of Carriacou. Roger's left hand is on the shell bed. The bed they are standing on has been densely burrowed by mud shrimps (=Thalassinoides isp.) and the "marlstones" in the face include deep-water traces such as Zoophycos isp.; thin sandstones stick out as ribs. 


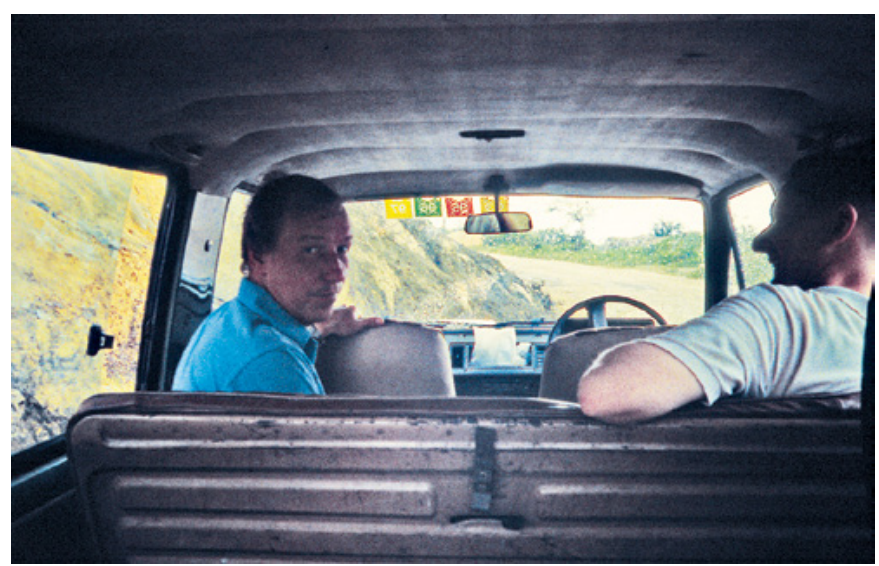

Figure 8. In the field vehicle in eastern Jamaica in early 1995. Ron (left) and David Keighley waiting for the driver. The exposure on the left is the Eocene Guys Hill Formation between Lichfield and Wait-a-Bit (stop 2 of Donovan 2002b).

\section{ACKNOWLEDGEMENTS}

This paper is based on an oral presentation by Donovan et al. at the May 2014 annual meeting of the Geological Association of Canada-Mineralogical Association of Canada (GAC-MAC) in Fredericton, New Brunswick. I thank the Naturalis Biodiversity Center for providing the financial support that enabled me to attend this conference. Fieldwork in Carriacou was supported by National Geographic Society grants \#5722-96, \#6625-99 and \#8445-08, which I gratefully acknowledge. Trevor A. Jackson (University of the West Indies, St. Augustine, Trinidad) kindly commented on an earlier version of this typescript. David A.T. Harper (Durham University, UK), Murray K. Gingras (University of Alberta, Edmonton) and Lynn T. Dafoe (Geological Survey of Canada-Atlantic, Dartmouth, NS) are thanked for their constructive reviews.

\section{REFERENCES}

Arnold, B.W. and Clark, H.L. 1927. Jamaican fossil echini. Memoirs of the Museum of Comparative Zoology, Harvard, 50, pp. 1-75.

Arnold, B.W. and Clark, H.L. 1934. Some additional fossil echini from Jamaica. Memoirs of the Museum of Comparative Zoology, Harvard, 54, pp. 139-156.

Blissett, D.J. 2006. Ichnology and sedimentology of the Cenozoic White Limestone Group, Jamaica, West Indies: with palaeobiogeographic implications. Unpublished Ph.D. Thesis, University of New Brunswick, Fredericton, xxviii+323 p.
Donovan, S.K. 1988. A preliminary biostratigraphy of the Jamaican fossil Echinoidea. In Echinoderm biology: Proceedings of the Sixth International Echinoderm Conference, Victoria, British Columbia, 23-28 August, 1987. Edited by R.D. Burke, P.V. Mladenov, P. Lambert and R.L. Parsley. Balkema, Rotterdam, pp. 125-131.

Donovan, S.K. 1993. Geological excursion guide 9: Jamaica. Geology Today, 9, pp. 30-34. http://dx.doi. org/10.1111/j.1365-2451.1993.tb00973.x

Donovan,S.K.2002a. A new ichnospecies of Gastrochaenolites Leymerie from the Pleistocene Port Morant Formation of southeast Jamaica and the taphonomy of calcareous linings in clavate borings. Ichnos, 9, pp. 61-66. http:// dx.doi.org/10.1080/10420940216418

Donovan, S.K. 2002b. Field guide to the geology of the Eocene Chapelton Formation (Yellow Limestone Group), western Central Inlier. Caribbean Journal of Earth Science, 36 (for 2001), pp. 39-47.

Donovan, S.K. 2007. H.L. 'Hal' Dixon (1941-2005) and the fossil echinoids of Jamaica. Caribbean Journal of Science, 43, pp. 279-282.

Donovan, S.K. and Harper, D.A.T. 1999. A new paleobathymetric interpretation of the Middle Miocene Grand Bay Formation of Carriacou (Grenadines, Lesser Antilles). Ichnos, 6, pp. 283-288. http://dx.doi. org/10.1080/10420949909386460

Donovan, S.K. and Miller, D.J. 1999. Report of a field meeting to south-central Jamaica, $23^{\text {rd }}$ May, 1998. Journal of the Geological Society of Jamaica, 33 (for 1998), pp. 31-41.

Donovan, S.K. and Pickerill, R.K. 1999. Fossils explained 26: Trace fossils 4 - borings. Geology Today 15, 197-200. http://dx.doi.org/10.1046/j.1365-2451.1999.1505007.x

Donovan, S.K. and Pickerill, R.K. 2013. On marls and marlstones. Bulletin of the Mizunami Fossil Museum, 39, pp. 127-128.

Donovan, S.K., Gordon, C.M., Littlewood, D.T.J., and Morris, S.F. 1989. Vagile benthos of a Late Pleistocene patch reef, Falmouth Formation, Jamaica. Palaeontological Association Annual Conference, Liverpool, Abstracts, p. 6.

Donovan, S.K., Jackson, T.A., and Pickerill, R.K. 1990. Report of a field meeting to selected localities in Portland, 5 May 1990. Journal of the Geological Society of Jamaica, 27, pp. 53-57.

Donovan, S.K., Jackson, T.A., Dixon, H.L., and Doyle, E.N. 1995. Eastern and central Jamaica. Geologists' Association Guides, 53, i+62 pp.

Donovan, S.K., Blissett, D.J., and Currant, A.P. 2001. Trace fossils of the Lower Pleistocene Manchioneal Formation of eastern Jamaica. Caribbean Journal of Science, 37, pp. 292-295.

Donovan, S.K., Pickerill, R.K., and Portell, R.W. 2002. A late Cenozoic 'root bed', an unconformity and the tectonic history of Carriacou, The Grenadines, Lesser Antilles. 
Proceedings of the Geologists' Association, 113, pp. 199205.

Donovan, S.K., Pickerill, R.K., Portell, R.W., Jackson, T.A., and Harper, D.A.T. 2003. The Miocene palaeobathymetry and palaeoenvironments of Carriacou, the Grenadines, Lesser Antilles. Lethaia, 36, pp. 255-272. http://dx.doi. org/10.1080/00241160310004666

Donovan, S.K., Renema, W., and Pickerill, R.K. 2005. The ichnofossil Scolicia prisca de Quatrefages from the Paleogene of eastern Jamaica and fossil echinoids of the Richmond Formation. Caribbean Journal of Science, 41, pp. 876-881.

Donovan, S.K., Pickerill, R.K., and Blissett, D.J. 2006. Collecting invertebrate trace fossils. Geological Curator, 8, pp. 205-210.

Donovan, S.K., Harper, D.A.T., and Marshall, J.D. 2011. Patrick John Brenchley (1936-2011). Geological Journal, 46, pp. 397-404. http://dx.doi.org/10.1002/gj.1318

Donovan, S.K., Waveren, I.M. van, and Portell, R.W. 2013. Island slopes and jumbled shell beds. Journal of the Geological Society, 170, pp. 527-534. http://dx.doi. org/10.1144/jgs2011-157

Donovan, S.K., Pickerill, R.K. and Keighley, D.G. 2014a. Classic localities explained 17: The Upper Pliocene Bowden shell beds, southeast Jamaica. Geology Today, 30, pp. 232-238. http://dx.doi.org/10.1111/gto.12079

Donovan, S.K., Blissett, D.J., and Keighley, D.G. 2014b. Ron under the Sun: Professor Ron Pickerill and the genesis of Antillean ichnology. Abstracts, Geological Association of Canada/Mineralogical Association of Canada Joint Annual Meeting, Fredericton, New Brunswick, May, p. 80.

Donovan, S.K., Blissett, D.J., and Pickerill, R.K. 2015. Jamaican Cenozoic ichnology: review and prospectus. Geological Journal, 50, pp. 364-382. http://dx.doi. org/10.1002/gj.2629

Etheridge, F.G. and Westcott, W.A. 1984. Tectonic setting, recognition and hydrocarbon reservoir potential of fan-delta deposits. In Sedimentology of gravels and conglomerates. Edited by E.H. Koster and R.J. Steel. Canadian Society of Petroleum Geologists, Memoir, 10, pp. 213-235.

Geological Survey Department. 1959. Jamaica geology: Scale 1:250 000. 1958 Provisional Edition. Directorate of Overseas Surveys, Tolworth, UK.

Hawkins, H.L. 1923. Some Cretaceous Echinoidea from Jamaica. Geological Magazine, 60, pp. 199-216. http:// dx.doi.org/10.1017/S0016756800085575

Hawkins, H.L. 1924. Notes on a new collection of fossil Echinoidea from Jamaica. Geological Magazine, 61, pp. 312-324. http://dx.doi.org/10.1017/S0016756800086465

Hawkins, H.L. 1927. Descriptions of new species of Cainozoic Echinoidea from Jamaica. Memoirs of the Museum of Comparative Zoology, Harvard, 50, pp. 7684.
Jackson, T.A. 1970. Geology and petrology of the volcanic rocks of Carriacou, Grenadines, West Indies. Unpublished M.Sc. thesis, University of the West Indies, Mona, 102 pp. James-Williamson, S.A. and Mitchell, S.F. 2012. Revised lithostratigraphy of the Coastal Group of south-eastern St. Thomas, Jamaica. Caribbean Journal of Earth Science, 44, pp. 9-17.

Jung, P. 1971. Fossil mollusks from Carriacou, West Indies. Bulletins of American Paleontology, 61 (no. 269), pp. 147-262.

McFarlane, N. (compiler). 1977. Jamaica - geology 1:250 000 sheet. Mines and Geology Division, Kingston.

Mitchell, S.F. 2004. Lithostratigraphy and palaeogeography of the White Limestone Group. In The mid-Cainozoic White Limestone Group of Jamaica. Edited by S.K. Donovan. Cainozoic Research, 3 (for 2003), pp. 5-29.

Mitchell, S.F., Pickerill, R.K., and Donovan, S.K. 1998. A unique pebble from the Pliocene Bowden Formation of southeastern Jamaica. Caribbean Journal of Science, 34, pp. 130-131.

Mitchell, S.F., Pickerill, R.K., Blackwell, B.A.B., and Skinner, A.R. 2000. The age of the Port Morant Formation, southeastern Jamaica. Caribbean Journal of Earth Science, 34 (for 1999), pp. 1-4.

Pickerill, R.K. 1974. Geology of the south Berwyn Hills, North Wales, with particular reference to Upper Ordovician marine benthic communities. Unpublished Ph.D. thesis, University of Liverpool, $\mathrm{xv}+515 \mathrm{p}$.

Pickerill, R.K. and Donovan, S.K. 1991. Observations on the ichnology of the Richmond Formation of eastern Jamaica. Journal of the Geological Society of Jamaica, 28, pp. 19-35.

Pickerill, R.K. and Donovan, S.K. 1997. Ichnology and biotic interactions on a Pleistocene gastropod from southeast Jamaica. Journal of the Geological Society of Jamaica, 32, pp. 19-24.

Pickerill, R.K. and Donovan, S.K. 1998. Ichnology of the Pliocene Bowden shell bed, southeast Jamaica. In The Pliocene Bowden shell bed, southeast Jamaica. Edited by S.K. Donovan. Contributions to Tertiary and Quaternary Geology, 35, pp. 161-175.

Pickerill, R.K. and Donovan, S.K. 1999. Ichnology of the late Cenozoic of southeast Jamaica: additional ichnotaxa and synthesis. Caribbean Journal of Science, 35, pp. 123-131.

Pickerill, R.K. and Mitchell, S.F. 1999. The graphoglyptid trace fossil Spiroraphe involuta (de Stafani, 1895) from eastern Jamaica. Journal of the Geological Society of Jamaica, 33, pp. 13-16.

Pickerill, R.K., Donovan, S.K., and Dixon, H.L. 1992. The Richmond Formation of eastern Jamaica revisited further ichnological observations. Caribbean Journal of Science, 28, pp. 89-98.

Pickerill, R.K., Donovan, S.K., and Dixon, H.L. 1993a. The trace fossil Dactyloidites ottoi (Geinitz, 1849) from the Neogene August Town Formation of southcentral 
Jamaica. Journal of Paleontology, 67, pp. 1070-1074.

Pickerill, R.K., Donovan, S.K., Dixon, H.L., and Doyle, E.N. 1993b. Bichordites monastiriensis from the Pleistocene of southeast Jamaica. Ichnos, 2, pp. 225-230. http://dx.doi. org/10.1080/10420949309380096

Pickerill, R.K., Donovan, S.K., Doyle, E.N., and Dixon, H.L. 1993c. Ichnology of the Paleogene Richmond Formation of eastern Jamaica - the final chapter? Atlantic Geology, 29, pp. 61-67. http://dx.doi.org/10.4138/1990

Pickerill, R.K., Donovan, S.K., and Dunn, J.T. 1995. Enigmatic cobbles and boulders in the Paleogene Richmond Formation of eastern Jamaica. Caribbean Journal of Science, 31, pp. 185-199.

Pickerill, R.K., Keighley, D.G., and Donovan, S.K. 1996. Ichnology of the Pliocene Bowden Formation of southeastern Jamaica. Caribbean Journal of Science, 32, pp. 221-232.

Pickerill, R.K., Donovan, S.K., and Mitchell, S.F. 1998a. Ichnology of the late Pleistocene Port Morant Formation of southeastern Jamaica. Caribbean Journal of Science, 34, pp. 12-32.

Pickerill, R.K., Mitchell, S.F., Donovan, S.K., and Keighley, D.G. 1998b. Sedimentology and palaeoenvironment of the Pliocene Bowden Formation, southeast Jamaica. In The Pliocene Bowden shell bed, southeast Jamaica. Edited by S.K. Donovan. Contributions to Tertiary and Quaternary Geology, 35, pp. 9-27.

Pickerill, R.K., Donovan, S.K., and Portell, R.W. 2002a. Caulostrepsis spiralis isp. nov., Miocene Grand Bay Formation of Carriacou (Grenadines, Lesser Antilles). Ichnos, 8 (for 2001), pp. 261-264.
Pickerill, R.K., Donovan, S.K., and Portell, R.W. 2002b. Bioerosional trace fossils from the Miocene of Carriacou, Lesser Antilles. Caribbean Journal of Science, 38, pp. 106-117.

Pickerill, R.K., Donovan, S.K., and Portell, R.W. 2003. Teredolites longissimus Kelly \& Bromley from the Miocene Grand Bay Formation of Carriacou, the Grenadines, Lesser Antilles. Scripta Geologica, 125, pp. 1-9.

Robinson, E. 1968. Biostratigraphic position of late Cainozoic rocks in Jamaica. Journal of the Geological Society of Jamaica, 9 (for 1967), pp. 32-41.

Robinson, E. 1994. Jamaica. In Caribbean geology: an introduction. Edited by S.K. Donovan and T.A. Jackson. University of the West Indies Publishers' Association, Mona, pp. 111-127.

Speed, R.C., Smith-Horowitz, P.L., Perch-Nielsen, K.v.S., Saunders, J.B., and Sanfilippo, A.B. 1993. Southern Lesser Antilles Arc Platform: pre-late Miocene stratigraphy, structure, and tectonic evolution. Geological Society of America Special Paper, 277, 98 p.

Trechmann, C.T. 1930. The Manchioneal Beds of Jamaica. Geological Magazine, 78, pp. 199-218. http://dx.doi. org/10.1017/S0016756800099246

Westcott, W.A. and Etheridge, F.G. 1983. Eocene fan deltasubmarine fan deposition in the Wagwater Trough, eastcentral Jamaica. Sedimentology, 30, pp. 235-247. http:// dx.doi.org/10.1111/j.1365-3091.1983.tb00667.x

Editorial responsibility: Robert A. Fensome 